\title{
Prison ideas and architecture 1850-today:
}

relevance to Norwegian prisoners and prison policy

Hedda Giertsen, Professor Emerita Department of Criminology and Sociology of Law University of Oslo

\begin{abstract}
This article discusses the use of prisons as punishment in Norway during the period 1850 to today. It looks at ideas about prisons and how they manifest themselves in prison sites and buildings. It also investigates the implications of various prison ideas and designs to prisoners and prison policy.

Parts of the article are based on an exhibition that took place in Oslo in 2018: Six Norwegian prisons 1850-today: Ideas, spaces, experiences. The exhibition included a total of 20 interviews in which prisoners were asked whether prison ideas and designs were relevant to them. The article ends with a discussion of the implications of architecture for prisons, their purposes, and their effects.
\end{abstract}

Keywords

Keywords: Norwegian prisons, history, architecture, prisoners' comments

\section{Norsk:}

Denne artikkelen diskuterer fengsel som straff i Norge fra 1850 til i dag. Den ser på fengselsidéer og hvordan de er kommet til uttrykk i fengselsområder, bygninger og interiør. Artikkelen spør videre om disse endringene, slik fengsler fremstår i dag, har betydning for fanger. Dette leder til en diskusjon om hvilken betydning fengselsidéer og arkitektur kan ha for fanger og for fengselspolitikken.

Artikkelen bygger for en stor del på en utstilling i Oslo i 2018: Six Norwegian prisons 1850-today. Ideas, spaces, experiences, som også omfatter 20 fangeintervjuer som formidler kommentarer om disse endringene har betydning for dem, eventuelt på hvilke måter. Artikkelen avsluttes med en diskusjon om hvilken betydning arkitektur kan ha i diskusjoner om fengsler, deres formål og virkninger 


\section{Introduction}

This article is about prison ideas and architecture; prisoners' experiences of various prison designs; and the position of architecture in prison policy. It describes prison ideas, their manifestation in sites and buildings from 1850 through today; and architectural contributions to these constructions. It looks for prisoners' comments on prisons from various epochs, as they appear today, and whether the variations are relevant to experiences of imprisonment. This leads to discussions on the position of architecture in prison policy and practice.

These 170 years comprise six epochs of prison ideas and designs; each of them represented in a prison site currently in use. Visiting the six prisons during the winter and spring of 2018 was like taking a 170-year time-travel through prison ideas and their manifestations (and revisions). Over the decades, these ideas centre around two main aims of prison policy: one aim is to punish, defined as inflicting an intended evil (the Norwegian High Court, p. 1207), today done by depriving convicts of resources, money and time in society. The other aim is to rehabilitate prisoners, by providing them with resources like work, education; social services, etc. (the Execution of Sentences Act; White paper, 2007-2008).

\section{Methods, material and main findings}

This article is based partly on materials from the exhibition Six Norwegian prisons 1850-today. Ideas, spaces, experiences, displayed in Oslo, in 2018 (Angelis et al). ${ }^{1}$ These consist of architectural drawings and photos from guided tours through the sites and buildings of the six prisons. In four of the prisons, the tour included the isolation units.

A total of 12 staff members informed us about their prisons. These staff included prison managers, inspectors in charge of administrative sections and prison officers. We had meetings with the assistant director of the Norwegian Directorate for Correctional Services, Sandlie $(2017,2018){ }^{2}$ and the chief en-

1. Norway was chosen as the exhibition's location because Norwegian prisons have been discussed in US media (e.g., Benko; Bertsch cited in Adler; Paddison; Moore) and today's Norwegian prison system includes functioning prisons from all six epochs.

The project was initiated by Sophia Angelis and carried out in cooperation with Elisabeth Tostrup, Zara Memarianpour and Hedda Giertsen. I want to thank the three others for a year of intense and enriching cooperation spent in preparing the exhibition; and for their thorough participation in this article. I also want to thank Lina G. Bull, Elisabeth Fransson, Inger Marie Fridhov and Guro $\varnothing$. Huby for their constructive contributions; as well as the article's anonymous peer reviewers.

2. Sandlie provided the needed permission for our access to the prisons, and the architectural drawings of the prisons. 
gineer Laeskogen in the Norwegian Directorate of Public Construction and Property (Statsbygg).

In five of the prisons, we interviewed 20 prisoners, almost all of whom had been selected for us by the staff. All were males above 18 years; most were Norwegian and had spent many years in prison, some on several occasions. In this last respect, they differ from the majority of prisoners in Norway. The interviews followed a semi-structured interview guide and almost all were conducted in English, sometimes supplemented with Norwegian; and lasted from one to two hours. All quotes from prisoners derive from these interviews.

This selection of prisoners is not representative of any prisoner population, but their comments point to experiences and considerations that are relevant for our themes, and hopefully they will also be relevant to further discussions on the significance of prison ideas and architecture for prisoners and for prison policy.

\section{Continuity and change}

An overall finding, neither surprising nor unusual, was continuity and change. Prison ideas and design have been altered over the decades, but there is also a continuity of key features in prison policy, in design and practice. Rehabilitation measures show notable changes since 1850, when prisoners were kept in total isolation in their cells, up to today's regulated access to activities and welfare services. Since 1970, rehabilitation has included work, education, programmes and cultural activities. Some of these measures are part of the public welfare system, being legal rights of all citizens. In practice, they are often constrained, compared to services on the outside (e.g., Giertsen and Rua).

Today, most prisons have locations for a gym, health care, social welfare services, library etc. To various degrees, the equipment provided resembles what is available on the outside. But access to the activities is markedly restricted in frequency and in duration of use; and the access varies among the prisons.

Means of punishment such as control, force and isolation represent continuity in prison policy and are basically unchanged since 1850. Certainly, some of today's instruments are more sophisticated, like metal detectors; controls are more frequent and new methods are applied as part of prisons' drug policy in the control of prisoners' surroundings and their bodies (Giertsen; Angelis et al.). In isolation cells, material conditions are deprived. The experience of isolation does not change: deprivation of stimulation remains the same; and its damaging effects persist (CAT; CPT; Sivilombudet; Smith et al.). 


\section{Six generations of Norwegian prisons: ideas and manifestations}

Prisons of each of the six prison generations were opened in 1850, 1939, 1970, 1990, 2010 and 2015, each with specific characteristics that reflected ideas at the time.

\section{i. 1851: Isolation and repentance}

In the 1850s, the model of the Philadelphia prison was imported from the USA. It was based on an idea that combined solitary confinement and repentance with the intention to improve prisoners.

The first and largest of such prisons was Botsfengslet, in Oslo (1851-2017), with 240 prison places. It consisted of three wings with cells radiating out from one central control point, each wing containing large, open halls, three stories high, with cells accessed from galleries in each hall. Prisoners were completely isolated in their cells. Outdoor time was spent alone, in a small fenced yard, for one hour per day (Eskeland; Schaanning).

The destructive effects of isolation had been known in England for some decades and had been abolished as a main approach. Even so, in 1850, it was used as the principle for the Norwegian prison system, with optimistic expectations. The results were disastrous. After some years, the imposed isolation was slightly reduced (Schaanning).

Despite our current knowledge about its negative effects, isolation is still being used. Since 1970, its location has partly moved from ordinary cells to separate isolation units and cells. But prisoners are still locked up in their usual cells overnight as part of the daily routine. From 2020, isolation may once more take place in ordinary cells (see below).

Smith describes another continuity. The religious approach of $19^{\text {th }}$ century Pennsylvania prisons has its counterpart in modern ideas. He finds: "Two religious 'modes of operation' can be identified: religion as a power strategy and religion as a technology of the self« (Smith, p. 195).

\section{ii. 1939: Reforms and modernization}

Almost 80 years later, in 1939, lla prison was opened, influenced by the prison legislation of 1903. Isolation continued, but modernization began when principles of progress were applied to prison conditions; and the possibility of release on probation was introduced, along with some common spaces for prisoners. The interior was changed, and the cells were arranged on separate floors with guard stations on each floor. Recognition of the importance of health led to a gym and a health services room. The style of the main building reflected the functionalist architectural ideals of the 1930s. 
Ila prison has a complex history. ${ }^{3}$ Today, Ila prison and preventive detention institution has 124 cells for male prisoners. Of these, 67 are for prisoners on preventive detention. Sites and buildings have been renovated and extended, with large workshops for metal and wood production, small ones for crafts and a greenhouse. In 2021, a new building will be opened for six prisoners drawn from across the prison system, as an alternative to solitary confinement for prisoners with serious mental illness (Kriminalomsorgen, 2020a; 2020b, p. 41).

\section{iii. $\quad$ 1970: Industry and community}

Thirty years later, in 1970, Ullersmo prison was opened with 188 places for male prisoners, implementing new ideas on industry and community, based on the prison legislation of 1958. These ideas were materialized in two large workshops for metal and wood production to give possibilities for community during work hours, and for prisoners to experience work satisfaction. Workshops and housing units are sited in separate buildings so prisoners have to go to another building for work. The aim is to imitate daily life on the outside, to create a habit to be kept after release.

The principle of community was made manifest in the housing construction. The housing units, each containing 18 to 20 places, were equipped with a common space for prisoners to meet and talk, to have meals, watch TV, etc. But the space is too small to include all prisoners at a time, and some withdraw into their cells. The cells are small, $6 \mathrm{~m}^{2}$, »like a shoe box" one prisoner (1) said. Soon after the prison opened, a school was established on the site, and today it also houses small workshops.

The buildings are two floors high, in line with architectural ideals of the 1960s. The yard is large, flat and open, allowing for small groups to go for walks and for sports activities. Some prisoners considered this to be the best yard.

In 2017, a new three-storey building, Model 2015 (see below), was added to the site. In 2019, Ullersmo had a total of 286 places (Kriminalomsorgen, 2020a).

Ullersmo was modern in the sense of believing in progress, reason and, if not in freedom, then in possibilities and a future for the individual. This is a prison from the social democracy period. It was presented with optimism and a strong belief that its regime would be the answer to crime, like the belief in the 1850-prison idea presented 120 years earlier; maybe because both mirrored widespread thinking in these periods, experienced as forward-looking and self-evident, taken for granted by most people, until new ideas came to take their place.

iv. 1990: Progression and community

Twenty years later, in 1990, Bergen prison opened with 100 places, mostly for male prisoners and a some for female prisoners. It was based on the idea of

3. Ila prison, built as a prison for women, was never used as such. It was used a prison camp by the German occupiers. From 1950 onwards, lla has been part of the regular Norwegian prison system (Kriminalomsorgen, 2013). 
progression, which was not new, but now made manifest in the possibility for prisoners to advance from a restrictive unit to a less restrictive one in another building.

Unlike Ullersmo's large, institutional-style buildings, Bergen consists of several small buildings connected to each other, one to two storeys high, distributed across the site and adapted to the hilly landscape. The pitched roofs connect the building complex with local traditions.

Bergen has small workshops or educational rooms in wings connected to the housing units. Equally important to work seems to be the idea of small communities: the units have six to eight cells and sufficient common space for all. In some units prisoners and officers have meals together to encourage closer relations and 'dynamic security', that is, the control of prisoners by officers through personal relations. It displays one of several examples of a two-sided prison characteristic that combines humane values and increased control.

Since 1990, the prison has been extended by an additional isolation unit (2000) and a common space 'the lounge' (2017); and Unit M, a building with 32 cells (2005). In 2019, Bergen had 203 places (Kriminalomsorgen, 2020a).

\section{v. 2010: Normalization}

Twenty years later, in 2010, Halden prison opened with 252 places for male prisoner. The design was influenced by ideas of normalization, intended to resemble usual society "as far as possible« (White paper, 2007-2008).

As in Ullersmo, large workshops and housing units are located in separate buildings. Prisoners 'go to work' here as well, now with the intention for them to experience light and air, the changes of the day and to avoid a feeling of »being in a diving bell« (Statsbygg, 2010, p. 10).

Compared to Bergen, the units are larger, comprising 10-12 cells, which is »optimal« one prisoner said. Two large workshops and several, well-equipped small workshops cover a wide range of crafts, activities and education. In 2019, Halden had 277 places (Kriminalomsorgen, 2020a).

Halden is exceptional in its architecture and intentions: "[to] meet staff and prisoners in a friendly, non-authoritarian way« and to avoid imposing alienation by means of space, light and »the psychological effects of colours (Statsbygg, 2010, p. 14-16). Art decoration (an obligation for public buildings), has been considered as if it could function as an additional pain of imprisonment (Jahn et al., 2010, p. 20). In this architectural context, prisoners are regarded similarly to any other users of buildings, as being entitled to the best possible environments. Like other prisons, Halden has an isolation unit and security cells. Halden was awarded an architectural prize for "a well-considered use of measures to handle the difficult balancing of well-being and punishment" (Byggeindustrien, 2011).

Up to 2010, three distinct generations of prison have been replicated: the design of 1850 by 54 small prisons; Ullersmo 1970, by one prison; and Bergen 
1990, by two prisons. There is only one Halden and there will be no more, for yet another policy soon emerged.

\section{vi. 2015: Economy and efficiency}

Five years later, 'Model 2015' appeared, set up as additional buildings to UIlersmo and Eidsberg prisons, in 2017. Another two Model 2015 prisons were opened in 2020, replacing older prisons with a total of 300 places (Kriminalomsorgen, 2020c).

This standard model has 12 cells in a unit, and four units placed crosswise on each floor, so that the two floors comprise eight units and 96 cells. The units are located above the ground floor which comprises workshops, reception cells, rooms for body search, a grocery store for prisoners, a multipurpose room, etc.

Model 2015, a module construction technique, can be adapted to the environment (Andersen, undated). The cells of $9.8 \mathrm{~m}^{2}$, are larger than those of 1970. As in Bergen and Halden, they are equipped with bathrooms. The common space encompasses large, well-equipped kitchens. Small, fenced balconies are attached to each unit and prisoners are allowed access to them and to common space during regulated times of the day. The workshops in Model 2015 are small. In Eidsberg in 2018, they there were not sufficient workplaces for the prisoners. Once again, workshops and housing units are in the same building. In 2019, Eidsberg had 102 places (Kriminalomsorgen, 2020a).

Halden prison was awarded an architectural prize in 2010 (as noted above). Model 2015 has acquired two prizes based on other criteria. One was for introducing "standardized and industrialized « prison construction »with positive effects on expenses and efficiency" (Bygg; Kriminalomsorgen, 2018). The other is the Innovation prize, set up by Statbygg (undated). Standardized planning and construction save several millions of Norwegian Kroner, and allow the education of prison officers and the day-to-day running of prisons to be standardized (Andersen, undated). Elements of the prison interior are produced by prisoners at Halden, Ringerike and Ullersmo prisons, which further reduces costs. Agder prison is to have a school of art for prisoners, to produce artworks for new prisons (Statsbygg, undated).

Arguments about economy and efficiency have always been important, but have never been the main, official arguments about prisons. Documents about Model 2015 present no ideas on prison policy, other than general statements: "[to] reduce the damaging effects of incarceration as much as possible ... ." (Statsbygg and Kriminalomsorgsdirektoratet, 2015, p. 10). ${ }^{4}$

Further changes are underway. When Agder prison opened in 2020, the Minister of Justice noted the digitization of prison processes, to increase security efficiency and prisoners' access to electronic communications with prison staff, public offices outside the prison and with family and friends (Kri-

4. In 2009, Statsbygg took over the responsibility for the building and maintenance of prisons, in cooperation with Kriminalomsorgen (Byggeindustrien, 2009). 
minalomsorgen, 2020c). "Agder is a prison adapted to the future (Sannerud, 2020). Such changes may ease prisoners' communication with staff, but they may also decrease the frequency of in-person encounters with staff, family and friends. At this opening, the prison authorities did not comment on the possible consequences of digitization to human relations concerning prisoners, staff and prisons as institutions.

In 2015, for the first time since 1850, ideas on prison policy are absent in public documents, while the building and operations of prisons are presented as the main objectives. In this way, the objectives of prisons are removed from the political sphere to the administrative context. This may reduce the relevance of values, human rights and the social and individual effects of imprisonment in public debates about prison as punishment.

This review of prison ideas and their manifestations in sites and buildings for 170 years, shows the enthusiasm with which prison authorities introduce each new idea of a prison. What do prisoners comment about the various ideas of prison, buildings and regimes they encounter; and do prison ideas and design matter to them?

\section{Prisoners' comments on prison ideas, buildings and imprisonment}

This section, describing prisoners' comments on prisons, is based on interviews with 20 prisoners (see above). These did not give a clear answer to the initial question about experiences of ideas and designs from the six epochs, but cut across these categories. Some commented on practical features of the interior; but mainly, the comments focused on other experiences (for further quotes, see Angelis et al.).

»The architecture, for me?" one prisoner (2) said, »I didn't think about it before now". General questions about architecture proved too abstract and useless (as they would to most people); while questions about cells, windows, light and air elicited answers about preferences. In new and renovated buildings, prisoners appreciated windows without bars and wide panes; for some, they gave pleasant views and let in a lot of light; while one prisoner had covered his window with a blanket. The ventilation hatch of the new windows, let in too little fresh air. Some noted the high level of noise in old prisons, and a considerably lower noise level in the new prisons.

When we started interviews with questions about the cell interior, prisoners would soon link the topic to an important concern for them; to what extent the design influenced possibilities for social relations. In these comments, features of the design were recognized when intertwined with experiences that were important to prisoners. ${ }^{5}$

5. I want to thank to Elisabeth Fransson for contributing this argument. 
Experiences from old and new prisons and from the ongoing restoration of old prisons (from 1850 to 1970), gave possibilities for comparing the location of toilets: having a toilet in the cell is an improvement for practical reasons, as prisoners no longer have to wait "for an hour or a half (prisoner 3) for an officer to escort them; nor to seek out solutions like »the trashcan or a bottle« (3). A further dimension to this was brought up by a prisoner (4): if you are isolated all the time, it is good not to have a toilet in the cell, because when you need to use the toilet outside, you must call for an officer, "and then you have some human contact . The main theme is about social contact, as in the following comment. Here, a prisoner (5) compared a new common space for prisoners with special needs to previous conditions which were: "a very small space. ... no TV room or living room and a very small kitchen. ... So, then people ... I want to say, butted heads, because it was a very small space. But, when they opened this new part [a large room with high ceiling], it was just, steam that just: 'Whooshhh!' People got the room they needed, then they could walk more freely, and then there was not so much conflict between people anymore."

Another prisoner (6) pointed to another effect of locating toilets within the cell: it is convenient to staff, as it eases the job of effectuating isolation: »[T] he flipside to it is that if they want, they just lock you in, and you don't have to go outside for toilet«. This may lead to an increasing use of isolation in ordinary cells, which would be another and negative effect of toilets in the cell. This prisoner (6) saw Model 2015 in the same way: "These new, nice, big cells are not for the prisoners, more humane things, but because of the guards [their work becomes easier]. « They may appear as humane improvements to prisoners, but he observed another function: »In [Prison] ... two guards were sick, they closed down the blocku. In a security and efficiency context, Model 2015 makes it easier to isolate prisoners in ordinary cells instead of moving them to the isolation unit. This may increase the risk that not all isolations are registered, which is already a problem (Kriminalomsorgen, 2020b, p. 34).

To other prisoners, social relations dominate prison design: »/t doesn't really matter how your cell looks, if it's small or ... big. It's about who they put you together with, in the avdeling [unit], actually.... This is the main thing in prison« (prisoner 7). Being asked whether he would prefer to be in a new prison, another prisoner (1) said: »/t depends on the people that are there. You get better cell, bigger cell. ... But you know, it's not the building that rehabilitates you when you have the sentence." Some prisoners preferred 1970 Ullersmo to 2010 Halden and applied to move there (cf. John K.).

In prisoners' comments, the relevance of design varies. Comments on matters like light and noise relate to practical matters. In other comments, design becomes relevant when integrated with prisoners' concern with social relations; and with comments on how prisons are run and the prioritization of efficiency. Several comments on design are basically about relations to other people. In comments about control and isolation, design is not mentioned. 


\section{Control and isolation}

Control and security have priority in prison policy (the Execution of Sentences Act $\S \S 2,3)$. They are expressed in walls, fences and interiors; they are effectuated when prison officers investigate prisoners and cells; and they set the stage for activities and relations that take place within prison walls. Control, force and isolation were commented upon by several of the prisoners interviewed, but their comments do not refer to the design.

Today, CCTV is installed to survey all prison space, except for the cells: „So, you are watched now ... in the daytime as long as you are out of the cellk. Did prisoners feel they had privacy in the cell, outside surveillance areas? »No, no, not much, because they [prison officers] can open the door when they want. They search the cell when they want. ... We don't have privacy, but you can't expect anything else« (prisoner 1).

The usual controls include monitoring urine tests and investigating clothes and stripped bodies (visitation). Most prisoners are subject to such controls, being routine before and after visits and leaves. Only a few prisoners talked about it. (There may be several reasons for this lack of comments; most likely, it is not because such controls are unimportant to prisoners). Prisoner 6 said: "... sometimes they [prison officers] just: 'Okay, you come with me!' and then you have to go into a room and strip for them, and then you have to go down and do the squats and everything. And this is not so nice." Some prisoners spoke about other prisoners' experiences:

»If there has been some kind of conflicts ... then they may go to the isolation unit, and people are sitting there for many months.... They have drug problem, ADHD. They are locked up for 23 hours a day. They go crazy. Everybody would do that. ... 'If you treat me like a dog, I become a dog'»(prisoner 9).

A few commented on their own experiences: "/solation does something to the psyche. I felt that when [I] was in [Isolation unit] and I could not go out" (prisoner 5). Another (prisoner 6) said: »This isolation block in [Prison] - yeah, well, it is hard to explain. It has got to be experienced; I think. This is not a place you want to be.« Prisoner 6 had been in isolation for years:

"Ah - I spent [many years] in [Prison] in avdeling [X], I never saw one other prisoner. I didn't hear one sound. I think this is worse [than noise]. ... And [you are all] by yourself. ...

I spent my time in isolation and it is not a particularly nice place to be."

He got through this by training and reading »Or you will go insane«. Most prisoners do not cope in this way, with deleterious effects, which also show up in suicide rates (Hammerlin, 2018; Morthorst et al.).

In four of the prisons, we were shown the isolation unit. The appearances of various isolation cells are devastating in their deprivation of stimulation; the security cells, stripped to nothing; and the belt-bed cells with their additional potential for constraint. The small outdoor yards of the isolation units usually 
have concrete walls; only in Halden was a window, with a view to plants and rocks, intended to provide relief.

Prisoners' comments on experiences of control and isolation, left design uncommented. This does not mean that design is irrelevant to prisoners; but that in some contexts, other features of the situation dominate their experiences. Prisoners' comments on observations and reflections make questions of the position of prison design in prison policy more challenging.

\section{The position of architecture in prison policy}

Section three describes six generations of prison ideas and their impact on prison design; and also, the impact of architectural knowledge, traditions and emerging trends on the constructions.

Here, the discussion of the impacts of design on prison policy and practice begins with the formal positions of architects and their clients. Prison policy and administration authorities develop prison ideas, and they act as the client of prison building projects, setting their terms (in 2009, Statsbygg overtook this responsibility in cooperation with Kriminalomsorgen [see FN. 5]). This relationship is reflected in documents on Halden prison: »The intention of the project builds on two interdependent opposites: stern and soft (Statsbygg, 2010, p. 8). This double aim of prison policy runs through the construction of Halden prison; also seen in the reasons for awarding it the architectural prize in 2010, which point to the way the architects handled the two aims: "the difficult balancing of well-being and punishment" (see above).

Clearly, prison design enables prison staff to implement prison punishment through control, force and isolation. Standing in front of a prison, its walls and fences, there is no doubt that the architecture establishes prisons as places of punishment - which is no coincidence. From the perspective of the socio-material spheres of acts, sites and buildings, like any man-made surroundings, demonstrate the materialization of intentional acts. Buildings, sites and city districts convey messages of dominance and burden, relief and leisure or of indifference (Østerberg, p. 122). In contemporary societies, prisons are one of the manifest expressions of state power. Entering a prison, these messages continue: when passing the entrance controls and continuing further into the building, the surveillance of all one's movements through corridors and units, delivers a continuous command to adapt to the setting whether one agrees to it or not. These surroundings send a continuous message to prisoners that they are dangerous and unreliable (Ribe-Nyhus). On this point, prison design accords with prison policy, maintaining control and security as its priority.

Like prison buildings, the design of spaces for punishment is a social matter, conveying messages to prisoners about how they are perceived. When prisoners do not comment on these spaces, it can be seen as a statement. To talk about the positive features of prison design, means to talk about oneself 
in a limited and fairly mundane context, resembling those on the outside. To talk about spaces of control, force and isolation, opens the way for other messages that may revive the pains, burdens and humiliation of imprisonment (Hammerlin, 2015). Not to talk about these situations, may be to avoid talking about the most damaging experiences of imprisonment, those that challenge one's identity.

Prison buildings and interiors also mirror rehabilitation, the other aim of prison policy, made manifest in spaces for work, education and welfare services. Contrasting with controls, these settings are more in accordance with the settings people experience in society. Sometimes, prisoners appreciate taking part in such activities to experience a temporary break from the prisoner position. This happens when they enter the position as a student, worker or client, and lasts until they return once more to the prisoner position (Becher; Donohue; Viljugrein).

In designing prisons, architects do not only adhere to the terms set by their client; they also provide their professional contributions to prison design. Documents on Halden prison feature architects' knowledge and considerations regarding basic human needs for air, light, view, colours etc. Here, prisoners and staff are encountered in the same way as any other inhabitant of a building, which accords with the principle of humane conditions expressed in the White paper (2007-2008) (see Haugerud, 2011).

This does not necessarily mean that prison design contributes to the prison policy aims of rehabilitating prisoners and reducing crime, nor that it should do so. The effects of rehabilitation methods are difficult to measure (Mathiesen; Drake.); the same goes for the impacts of prison design. For several reasons, it is difficult to track the effects of environment and design on prisoners' behaviour and any eventual reduction in crime (Moran et al., p. 118). Just as most rehabilitation strategies have other rationales beyond rehabilitation (based in laws on welfare services and general standard of living), there are also some general standards on the minimum material prison conditions, independent of any consequences.

The design of buildings and interiors may influence people in positive ways, as stated by Murphy, a US architect (cited in Adler): "Architecture is always shaping behavior ... It's on the spectrum of behavioral science and art form. No architecture more so than prisons proves that's the case."

Design does not intervene in the basic frames of prisons. In the US, with its extraordinary rate of imprisonment, this has been a central theme to some architects: „The problem of mass incarceration is a policy problem - it's not at its root a design problem « (Sperry cited in Adler). "[Sperry] is the president of the San Francisco-based Architects/Designers/Planners for Social Responsibility. ... He has long advocated that architects should boycott prison design altogether. His idea is that the resources devoted to imprisonment should go instead to 'justice reinvestment'.." 
An Italian architect, Fagnoni, contributes to the discussion on prison ideas and designs, with a design for 'the City Confined'. This idea of 'prison as village', integrates the required restrictions and aims to improve "the dignity and life of the prisoners (Fagnoni, p, 129).

Some of its features differ from usual high security prison control regimes. In the 'prison as village' design, the prison wall and the surveillance system, allow prisoners to move around on the site. This may reduce the usual control routines like cell-checking, counting and visitation. The surveillance works by a badge linked to the identity of all prisoners and staff, and controls their movements within the site, according to plans. Such complete surveillance may be experienced as burdensome but is perhaps less so than videotaped surveillance displayed on screens, watched by prison officers. More importantly, also in relation to security, seems to be the inclusion of prisoners in work like running the prison, agriculture, workshops and in education. Thus, electronic installations will be used, not as alternatives to direct human contact (as in Agder prison, described earlier), but to increase possibilities for direct human contact within the site. Cells comprise two or four beds; there are no single cells (such as dominate in Norwegian high security prisons).

Efficiency and economy direct choices of technical solutions to handle energy; water and waste, combined with installations sustaining the environment, like photovoltaic panels. These may provide possibilities for professional education for prisoners. This 'village prison' has spaces for solitary confinement, located on the top floor of the housing units. The village prison contributes to the discussion of prison ideas as well as to the design of sites and buildings. In 2001, this project won the first prize in a competition on $» a$ prototype of a medium-security prison for the custody of 200 detainees", within »a Regulation which give voice and emphasis to alternatives in detention« (Fagnoni, p. 129).

\section{End}

This article is about ideas on prison as punishment and their manifestations in prison design from 1850 through today, in Norway. These 170 years comprise six generations of prisons, from 1850, 1939, 1970, 1990, 2010 and 2015; and the ideas of this period centre around two main prison policy aims: to punish and to rehabilitate. The ideas and manifestations show continuity and change. Since 1850, the main characteristics of punishment, control and isolation, continue; though some control measures have changed, while the isolation remains the same. Different from those in 1850, rehabilitation measures have been basically the same since 1970, with some improvements. By 2015, official arguments on prison focus on efficiency and economy, leaving out ideas about prisons. 
Prison architects follow the main ideas of their clients, which are the prison authorities and Statsbygg; but they also influence the design of sites and buildings according to architectural traditions and contemporary trends.

This points to questions about whether design matters to prisoners and whether they notice variations in the various prison ideas and designs. Comments from interviews with 20 prisoners, cut across the prison generations. Some comments focused on practical matters; in other comments design was relevant when integrated with prisoners' concerns about social relations; while in yet other comments design was not mentioned, as in those about experiences of control and isolation. Design does not hold an independent, important position in prisoners' comments.

The last section describes three examples of positions on prisons, held by architects; one is to use one's knowledge to improve conditions for prisoners, as for any group of inhabitants. Another position is to take part in the prison discussion, boycott prison design and try to get the money redirected to other "justice investments". A third position is to intervene in the usual prison idea and design found in most European countries, and propose the idea of a 'village prison'.

Kontaktoplysninger

Hedda Giertsen: hedda.giertsen@jus.uio.no

\section{References}

Adler, J. (2019). Architecture and Prison Reform. Architectural Record, March 4, 2019; and on: Criminal legal news [Online]. Available at

https://www.architecturalrecord.com/articles/13919-architecture-and-prison-reform/ (Accessed 15 October 2020).

Andersen, B.O. (undated). (Videotape) Agder fengsel [Agder prison]. Statsbygg [Norwegian Directorate of Public Construction and Property and the Norwegian Correctional Service]. [Online]. Available at

https://www.youtube.com/watch?v=5NuoXic1Qql\&feature=emb_imp_woyt (Accessed 13 October 2020).

Angelis, S., Giertsen, H. and Tostrup, E. (2018). Six Norwegian Prisons. Pamphlet. Oslo: Oslo School of Architecture and Design (AHO). [Online]. Available at

https://aho.no/no/kalender/exhibition-six-norwegian-prisons-ideas-spaces-and-experiences (Accessed 15 October 2020). [Online]. Available at sixnorwegianprisons.com.

Becher, C. (2007). Friminutt i fengsel - en kvalitativ studie av fangerollen i fengsel [Recess in prison - a qualitative study of the prisoner role in prison]. Master thesis. Oslo: Department of Criminology and Sociology of Law, University of Oslo

Benko, J. (2015). The Radical Humaneness of Norway's Halden Prison. New York Times Magazine. March 26, 2015. [Online]. Available at

https://www.nytimes.com/2015/03/29/magazine/the-radical-humaneness-of-norwayshalden-prison.html. (Accessed 31 January 2021).

Bygg 21 (2018). Beste praksis-pris til Statsbygg og Kriminalomsorgsdirektoratet [Prize for best practice to the Norwegian Directorate of Public Construction and Property and The Norwegian Directorate for Correctional Services.] [Online]. Available at 
https://www.bygg21.no/artikler/nyheter/beste-praksis-pris-til-statsbygg-og-kriminalomsorgsdirektoratet/ (Accessed 25 October 2020).

Byggeindustrien [The industry of Construction] (2009). [Online]. Statsbygg har overtatt fengslene [The Norwegian Directorate of Public Construction and Property has taken over the prisons]. Available at http://www.bygg.no/article/40219 (Accessed 25 October 2020).

Byggeindustrien [The industry of Construction] (2011). Pris til Halden fengsel [Prize to Halden prison] [Online]. Available at http://www.bygg.no/article/60185 (Accessed 15 October 2020).

CAT (The Convention against Torture and Other Cruel Inhuman or Degrading Treatment or Punishment) (2019). Reporting status for Norway. United Nations Human Rights, Office of the High Commissioner. [Online]. Available at

https://tbinternet.ohchr.org/_layouts/TreatyBodyExternal/Countries.aspx?CountryCode $=$ NOR\&Lang $=\mathrm{EN}$ (Accessed 24 January 2019).

CPT (The European Committee for the Prevention of Torture and Inhuman or Degrading Treatment or Punishment) (2019). The CPT and Norway. [Online]. Available at https://www.coe.int/en/web/cpt/norway (Accessed 24 January 2019).

Donohue, E. \& D. Moore. (2009). When is an offender not an offender? Power, the client and shifting penal subjectivities. Punishment and Society, vol. 11, no., pp. 319-336. https://doi.org/10.1177/1462474509334174

Drake, D. (2012). Prisons, punishment and the pursuit of security. Palgrave Macmillan. https://doi.org/10.1057/9781137004833

Eskeland, S. (1989). Fangerett. En studie av rettssikkerhet ved fullbyrdelse av fengselsstraff [Prisoners' Rights. A Study of rule of law by implementing imprisonment]. Oslo: Tano

Execution of Sentences Act. (Act relating to the execution of sentences etc.) 2001. (LOV-2001-05-18-21). [Online]. Available at https://lovdata.no/dokument/NLE/lov/2001-05-18-21 (Accessed 31 October 2020).

Fagnoni, P.M. (2018). The City Confined. In: Franssom, E., Giofrè, F. and Johnsen, B. (eds) Prison, Architecture and Humans. Oslo: Cappelen Damm Akademisk.

Giertsen, H. (2012). Increased control, answers to poverties and looking for a life after release. Nordic Studies on Alcohol and Drugs vol. 6, no 29, pp. 589-604.

https://doi.org/10.2478/v10199-012-0049-0

Giertsen, H. and Rua, M. (2014) Møtested for straff og velferd. Rusmestringsavdelinger i fengsel. [A meeting place for punishment and welfare: Drug-management units in prison]. Nordisk Tidsskrift For Kriminalvidenskab vol. 101, no 2, pp. 158-182. [Online]. Available at

https://tidsskrift.dk/NTfK/article/view/70167 (Accessed 31 January 2021). https://doi.org/10.7146/ntfk.v101i2.70167

Hammerlin, Y. (2015). Et fengsel er et fengsel, men ... [A prison is a prison, but ... ]. Psyke og Logos vol. 36, no 1, pp. 129-152. [Online]. Available at https://tidsskrift.dk/psyke/article/view/22831 (Accessed 31 October 2020).

Hammerlin, Y. (2018). Fengselslivet som en livstruende byrde [The life in prison as a threat to life]. Suicidologi vol. 23, no 3, pp. 10-22. [Online]. Available at https://journals.uio.no/suicidologi/issue/view/632/226 (Accessed 31 January 2021). https://doi.org/10.5617/suicidologi.6766

Haugerud, M. (2011). De gode intensjoners tukthus - Fem teser om straffens idealer og fengslets realiteter fra et fangeperspektiv [The good intensions of the reform prison - Five thesis on the ideals of punishment and realities from a prisoner perspective]. In: Juss-Buss and Halvorsen, $O$. (eds) Med loven mot makta. Juss-Buss forti år [With the law against the power. Juss-Buss forty years]. Oslo: Novus forlag.

Jahn, E., Johnsen, H.H. and Aas, A. (2010). Kunstprosjektet [The art project]. In: Halden fengsel. Berg i Østfold. Nybygg NR. 686 [Halden prison. Berg in Østfold. New building 
Nr. 686]. Oslo, Statsbygg [Norwegian Directorate of Public Construction and Property]. [Online]. Available at http://docplayer.me/2797405-Halden-fengsel-berg-i-osfold-nybygg-nr-686-2010.html (Accessed 16 October 2020).

John, K. (2018). Humanity Rather than Materialism - A Short Essay About the Prison Environment. In: Fransson, E., Giofrè, F. and Johnsen, B. (eds) (2018). Prison, Architecture and Humans. Oslo: Cappelen Damm Akademisk. [Online]. Available at

https://press.nordicopenaccess.no/index.php/noasp/catalog/book/31 (Accessed 29 October 2020).

Kriminalomsorgen [Norwegian Correctional Service] (2013). Ila fengsel og forvaringsanstalt. Historikk [lla prison and preventive detention institution. History]. Kriminalomsorgen [The Norwegian Correctional Service]. [Online]. Available at https://ilafengsel.no/historikk.html (Accessed 31 January 2021).

Kriminalomsorgen [Norwegian Correctional Service] (2018). Byggepris til kriminalomsorgen og Statsbygg. [Prize on construction to the Norwegian Correctional Service and the Norwegian Directorate of Public Construction and Property]. [Online]. Available at http://www.kriminalomsorgen.no/byggepris-til-kriminalomsorgen-og-statsbygg. 6138634-237613.html (Accessed 5 January 2019).

Kriminalomsorgen [The Norwegian Correctional Service] (2020a). Kriminalomsorgens årsstatistikk 2019 [The Norwegian Correctional Services. Annual statistics 2019]. Lillestrom: Kriminalomsorgsdirektoratet [The Norwegian Directorate of Correctional Services]. [Online]. Available at

https://www.kriminalomsorgen.no/getfile.php/4768782.823.77npnkalujumpt/Kriminal omsorgens+\%C3\%A5rsstatistikk+2019.pdf (Accessed 10 February 2021).

Kriminalomsorgen [The Norwegian Correctional Service] (2020b). Kriminalomsorgen Årsrapport 2019 [The Norwegian Correctional Service. Annual report 2020]. Lillestrom: Kriminalomsorgen [The Norwegian Correctional Service]. [Online]. Available at https://www.kriminalomsorgen.no/getfile.php/4723841.823.jwijswnzsuilwb/\%C3\%85rsrapport+2019+for+kriminalomsorgen.pdf (Accessed 29 October 2020).

Kriminalomsorgen [The Norwegian Correctional Service] (2020c). Storfin åpning av nye Agder fengsel, avdeling Mandal [Spectacular opening of the new Agder prison, Mandal section]. Lillestrøm, Kriminalomsorgen [The Norwegian Correctional Service]. [Online]. Available at

https://kriminalomsorgen.custompublish.com/storfin-aapning-av-nye-agder-fengsel-avdeling-mandal.6320959-237613.html (Accessed 29 October 2020).

Laeskogen, S.E. (2017). Project manager in Statsbygg (the Norwegian Directorate of Public Construction and Property). Meeting with S. Angelis, H. Giertsen and E. Tostrup, 30 October.

Mathiesen, T. (2006) Prison on trial, 3rd edition. Winchester, Waterside press.

Moran, D., Jewkes, Y. and Turner, J. (2016). Prison design and carceral space. In: Jewkes, Y., Bennett J., and Crewe, B. (eds) Handbook on prisons. 2nd edition. London and New York: Routledge. https://doi.org/10.4324/9781315570860

Moore, M. (2017). Norwegian prison. Videotape. YouTube. [Online.] Available at https://www.youtube.com/watch?v=0lepJqxRCZY. (Accessed 15 January 2021).

Morthorst, B.R., Mehlum, L., Pàlsson, S.P., Mühlmann, C., Hammerlin, Y., Madsen. T., Nordentoft, M \& Erlandsen, A. (2020). Suicide Rates in Nordic Prisons 2000-2016. Archive of Suicide Research. [Online.] Available at https://doi.org/10.1080/13811118.2020.1746943 (Accessed 30 November 2020).

Norwegian High Court (1977). Norsk Retstidende.

Paddison, L. (2019). How Norway Is Teaching America To Make Its Prisons More Humane. 
The broken prison system is in desperate need of reform. U.S. prisons are trying to find answers overseas. Huffington Post. August 22, 2019. [Online]. Available at

https://www.huffpost.com/entry/norway-american-prison-system-reform_n_5d5ab 979e4b0eb875f270db1?guccounter=1\&guce_referrer=aHR0cHM6Ly93d3cuZ29vZ2xILm NvbS8\&guce_referrer_sig=AQAAAEf6fu2WhXugojdjE-o6PB6tsdONjfRGCYifXuuvkbmzi Khdd-dLEiZsdWAB1g7PEmXn_aonchUxGrLo5E68xSPFS2mzs06NF4YwgdPfAeZBXTyLoAi 89Kdkb1igELA4K9BC4SdZaJ5BKBu0yhd8uCS3op7GUEVJ7s4oN_pDsx3B (Accessed 31 January 2021).

Ribe-Nyhus, A. (2020). »Indre og ytre soning " ["To serve a sentence, from within and from the outside«]. PhD i studier av profesjonspraksis no. 34-2020 [PhD in studies of practice of professions]. Bodø: Fakultetet for lærerutdanning og kunst- og kulturfag, Nord Universitet.

Sandlie, J.E. (2017). Assistant director of Kriminalomsorgsdirektoratet (the Norwegian Directorate for Correctional Services). Meeting with S. Angelis 14 September.

Sandlie, J.E. (2018). Assistant director of Kriminalomsorgsdirektoratet (the Norwegian Directorate for Correctional Services). Meeting with S. Angelis and H. Giertsen 29 May.

Sannerud, L. (2020). Storfin åpning av nye Agder fengsel, avdeling Mandal [Spectacular opening of the new Agder prison, Mandal section]. Kriminalomsorgen [The Norwegian Correctional Service]. [Online]. Available at

https://kriminalomsorgen.custompublish.com/storfin-aapning-av-nye-agder-fengsel-avdeling-mandal.6320959-237613.html (Accessed 25 October 2020).

Schaanning, E. (2007) Menneskelaboratoriet. Botsfengslets historie [The laboratory on humans. The history of Botsfengslet (the Prison of Repentance)]. Oslo: Scandinavian Academy Press / Spartacus forlag.

Sivilombudet [The Ombudsman] (2020). Torturforebygging [Torture Prevention]. Oslo: Nasjonal forebyggingsenhet mot tortur og umenneskelig behandling [The national unit for prevention of torture and inhumane treatment]. Oslo: Sivilombudet. [Online]. Available at

https://www.siv[ilombudsmannen.no/torturforebygging/mandat/ (Accessed 27 October 2020).

Smith, P.S. (2004). A religious technology of the self. Rationality and religion in the rise of the modern penitentiary. Punishment and Society, vol 6, no. 2, pp. 195-220. [Online]. Available at https://journals.sagepub.com/doi/pdf/10.1177/1462474504041265 (Accessed 15 October 2020). https://doi.org/10.1177/1462474504041265

Smith, P.S., Horn, T. Nilsen, J, F., Rua, M. (2013). Isolasjon i skandinaviske fengsler. Skandinavisk praksis og etableringen av et skandinavisk isolasjonsnettverk [Solitary confinement in Scandinavian prisons. Scandinavian practice and the establishment of a Scandinavian network on solitary confinement]. Kritisk juss, vol 39, no. 3-4, pp. 170-191. [Online]. Available at https://www.jus.uio.no/ikrs/english/research/networks/scandinavianstudiesofconfinement/index.html (Accessed 15 October 2020).

Statsbygg [Norwegian Directorate of Public Construction and Property] (2010). Halden fengsel. Berg i Østfold. Nybygg NR. 686 [Halden prison. Berg in Østfold. New building Nr. 686]. [Online]. Available at http://docplayer.me/2797405-Halden-fengsel-berg-i-osfold-nybygg-nr-686-2010.html (Accessed 16 October 2020).

Statsbygg [The Norwegian Directorate of Public Construction and Property] (undated). Agder Prison. Video. [Online]. Available at

https://www.youtube.com/watch?v=5NuoXic1Qql\&feature=emb_imp_woyt (Accessed 15 October 2020).

Statsbygg and Kriminalomsorgsdirektoratet [Norwegian Directorate of Public Construction and Property and The Norwegian Directorate for Correctional Services] (2015). 
Funksjons- og arealveileder. Kravspesifikajson for fengselsbygg [Supervisor to function and area. Specification for prison buildings. Consultation draft]. 1.1; 26.06.2015.

Viljugrein, T. (2002). Skole, språk og fengsel. Undervisning av mannlige minoritetsspråklige fanger i fire norske fengsler [School, language and prison. Education for male minority language speakers]. Evalueringen av fengselsundervisningen [Evaluation of the prison education]. Report no. 1/02. Bergen: Statens utdanningskontor i Hordaland.

White Paper no. 37. (2007-2008) Straff som virker - mindre kriminalitetet - tryggere samfunn (kriminalomsorgsmeldingen) [Punishment that works - less crime - safer society]. Oslo, The Ministry of Justice and Police. [Online]. Available at

http://www.regjeringen.no/nb/dep/jd/dok/regpubl/stmeld/2007-2008/stmeld-nr-372007-2008-.html?id=527624\&epslanguage=NO (Accessed 14 February 2020).

Østerberg, D. (2011). Kritisk situasjonsfilosofi [Critical situational philosophy]. Oslo: Gyldendal. 